\title{
The Influence of Regular Physical Activity on the Cell-Mediated Immunity in Pigs
}

\author{
By Marianne Jensen \\ Swedısh University of Agricultural Sciences, Faculty of Veterınary Medicıne, \\ Department of Medicine and Surgery, Uppsala, Sweden.
}

\begin{abstract}
Jensen, M.: The influence of regular physical activity on the cell-mediated immunity in pigs. Acta vet. scand. 1989, 30, 19-26. - The influence of moderate regular physical activity on the cell-mediated immunity was studied in growing pigs.

Ten anımals were subjected to physical trainıng on a large anımal treadmill, and 10 were kept in their pens throughout a 12-week experimental period.

Regardless of whether the pigs underwent training or not, a whole blood lymphocyte stımulation test performed at 3 stages of the experiment revealed an equal ability of the cells to respond to stimulation induced by pokeweed mitogen and phytohaemaglutınin.

The influence of serum from the pigs of the trained and untrained groups was studied in a stimulation test with purified mononuclear cells obtained from 2 healthy control pigs. The results indicated that no additional serum factors released by the physical training altered the blastogenic response of these lymphocytes.

It is concluded that moderate exercise should not be regarded as a stressor which alters the cellular immunity in pigs.
\end{abstract}

moderate exercise; stressors; lymphocyte stimulation test; peripheral blood lymphocytes; mitogens.

\section{Introduction}

Both the cell-mediated and the antibodydependent immune functions can be modulated by exposure to stressors such as heat, cold, mixing, crowding, shipping and exercise (for review see Kelley 1980). The influence of severe and acute stress may suppress the immune response of the animal concerned, whereas moderate forms of stress may do the reverse and enhance such a response (Monjan 1981).

Both acute physical exertion and endurance training can modulate the cell-mediated immunity (CMI), commonly reflected by the results of the in vitro lymphocyte stimulation test.

An impaired response of bovine (Blecha \& Minocha 1983) and equine (Kurz et al.
1987) peripheral blood lymphocytes (PBL) to mitogen stimulation has been referred to the stress effects of a single bout of exercise. Similarly, marathon running though not moderate running, caused a transient reduction in mitogen- and antigen-induced blastogenesis in humans (Eskola et al. 1978).

In the growing pig, physical activity is beneficial for a number of reasons. Improvement of the developing locomotor system is one of the most important ones, since leg weakness is a common problem in the modern pig industry (Reiland 1975). Physical training also improves the quality of meat, since pork of trained pigs retains its fluid-holding capacity better and has more intensive muscle colour than that of untrained pigs (Rülcker 1968). Furthermore, there is a growing demand 
among consumers of pork from pigs that have been brought up under a minimum of physical and psychological stress, i. e. under more natural conditions, a form of husbandry which also breeders are showing more interest in.

Consequently, more information is required concerning the relationship between exercise, stress and immunocompetence in the pig, as this is an extremely inactive animal susceptible to stress and prone to infectious diseases. The present study was therefore conducted to determine whether regular moderate exercise acts as a stressor in growing pigs and in that sense affects the blastogenesis of lymphocytes.

\section{Materials and methods \\ Animals}

Two litters of weaned crossbred (Swedish Landrace $\times$ Swedish Yorkshire) pigs were mixed and split into 2 groups, each consisting of 10 animals. One group was to undergo training and the other was to be left untrained. Both groups were housed in pens in the same stable and fed according to the SLU feeding scale (Andersson 1985). The animals were inspected daily for their clinical state of health.

Two healthy adult pigs (Swedish Landrace $x$ Swedish Yorkshire) were used as control animals in the lymphocyte stimulation tests, which were performed with purified mononuclear cells (MNC).

\section{Experimental design}

For a period of 12 weeks, one group of pigs was exercised once daily, 5 times a week, on a large-animal treadmill (Säto-treadmill, Uppsala, Sweden). During the first 3 weeks they ran a daily distance of $200 \mathrm{~m}$ at a speed of $1.5 \mathrm{~m} / \mathrm{s}$, in the next 3 week-period $350 \mathrm{~m}$ at a speed of $2.0 \mathrm{~m} / \mathrm{s}$ and in the latter half of the study $600 \mathrm{~m}$ at speeds of 2.0 to $2.5 \mathrm{~m} / \mathrm{s}$.
The pigs in the untrained group were left in their pens throughout the experimental period.

Blood samples were collected before, after 6 weeks and at the end of the 12-week experimental period.

In order to evaluate the effect of the exercise in terms of changes in the levels of oxidative enzymes, biopsy specimens from $\mathrm{m}$. biceps femoris were taken under general anaesthesia before and after the experimental period. The samples were immediately frozen in liquid nitrogen and stored at $-80^{\circ} \mathrm{C}$.

\section{Blood sampling}

So that as little stress as possible should be caused, the samples were taken by the people who handled the pigs daily. Blood was drawn from the external jugular vein into $10 \mathrm{ml}$ preservative-free heparinised and EDTA vacutainer tubes.

In order to count the number of cells included in the lymphocyte stimulation tests total and differential white cell counts were performed by standard methods at the Department of Clinical Chemistry of the Veterinary Faculty.

\section{Enzyme analyses}

Muscle tissue was freeze-dried, dissected free of blood, fat and connective tissue under a microscope, weighed (1.8-2.5 mg), and homogenised (1:400) in ice-chilled $0.1 \mathrm{~mol} / \mathrm{l}$ potassium phosphate buffer $(\mathrm{pH} 7.3$ ) in an ultrasound disintegrator.

The activities of the enzymes citrate synthase (CS), a marker of oxidative capacity, and 3-OH-acyl-CoA dehydrogenase (HAD), a marker of lipid oxidation, were assayed by fluorimetric techniques at $25^{\circ} \mathrm{C}$ as described previously (Essén et al. 1980, Essén-Gustavsson et al. 1984). Enzyme activities are expressed as $\mu \mathrm{mol} / \mathrm{g}$ dry weight $\times \mathrm{min}$. 


\section{Lymphocyte stımulation tests}

Lymphocyte stimulation tests were performed with whole blood obtained from the experimental animals before, after 6 weeks of and at the end of the experimental period.

The presence of serum factors that could affect the lymphocyte function was evaluated with purified MNC obtained from the control pigs. The culture medium was then supplemented with pooled serum samples obtained from the 2 groups of experimental animals or with Myoclon fetal calf serum before and after the experimental period.

Before the experiment started, and in accordance with findings in previous studies (Jensen et al., 1988), optimal conditions for the lymphocyte stimulation tests were established.

Whole blood lymphocyte stimulation tests. Whole blood from the experimental animals was diluted $1: 15$, corresponding to $1.2 \times 10^{6} \pm 0.04 \times 10^{6}$ lymphocytes (mean $\pm \mathrm{SEM}, \mathrm{n}=60$ ) per $\mathrm{ml}$, in growth medium supplemented with $2 \mathrm{mmol} / \mathrm{l}$ glutamine, 0.1 $\mathrm{mol} / \mathrm{l}$ Hepes, $100 \mathrm{IU} / \mathrm{ml}$ penicillin, 100 $\mu \mathrm{g} / \mathrm{ml}$ streptomycin and $20 \%$ fetal calf serum. One hundred microliters of the diluted blood was cultured in round-bottomed microtiter plates together with $100 \mu$ of growth medium (control cultures) or $100 \mu \mathrm{l}$ of phytohaemagglutinin (PHA; Pharmacia, Sweden), diluted 1:10 from a stock solution containing $1.71 \mathrm{mg}$ of lectin per $\mathrm{ml}$, or pokeweed mitogen (PWM; Sigma Chemical Company, St. Louis, USA) at a concentration of $5 \mu \mathrm{g} / \mathrm{ml}$. Quadruplicate cultures were incubated for $72 \mathrm{~h}$ at $37^{\circ} \mathrm{C}$. The cells were then pulsed with $0.25 \mu \mathrm{Ci}$ of radiolabelled thymidine in $20 \mu$ l of growth medium per well. The cultures were incubated for another $24 \mathrm{~h}$ before harvesting. The radioactivity in each culture was measured and counts per min. (cpm) from the quadruplicate wells were averaged.
Lymphocyte stimulation tests with purified MNC. Heparinised blood, obtained from the control pigs, was diluted with an equal volume of phosphate buffered saline (PBS) pH 7.2. The diluted blood was gently layered on a cushion of Ficoll-Paque (Pharmacia, Sweden) and centrifuged for $20 \mathrm{~min}$ at $400 \times \mathrm{g}$. The MNC were collected from the interface, washed 3 times in PBS and resuspended in the growth medium without serum.

The fetal calf serum, used in the whole blood lymphocyte stimulation test was replaced either by $20 \%$ Myoclon fetal calf serum or by $20 \%$ serum pools from the experimental animals.

The serum was obtained from the animals in the trained and the untrained groups before and after the 12-week experimental period. The serum samples were pooled, heat-inactivated at $56^{\circ} \mathrm{C}$ for $30 \mathrm{~min}$ and stored at $-20^{\circ} \mathrm{C}$ until used.

With the exception that $5 \times 10^{5} \mathrm{MNC}$ were used in each type of culture, these lymphocyte stimulation tests were performed in the same way as the whole blood stimulation test described above.

\section{Statistical analyses}

Paired or unpaired Student's $t$-tests were used for statistical evaluation of the results.

Enzyme activities are expressed as mean values \pm SEM.

Data obtained from the lymphocyte stimulation tests are expressed as mean counts per $\min \pm$ SEM.

\section{Results}

All animals remained healthy throughout the experimental period. In the trained group the activity of the oxidative enzyme $\mathrm{CS}$ in muscle tissue increased significantly ( $p$ $<0.01)$ from the beginning to the end of 


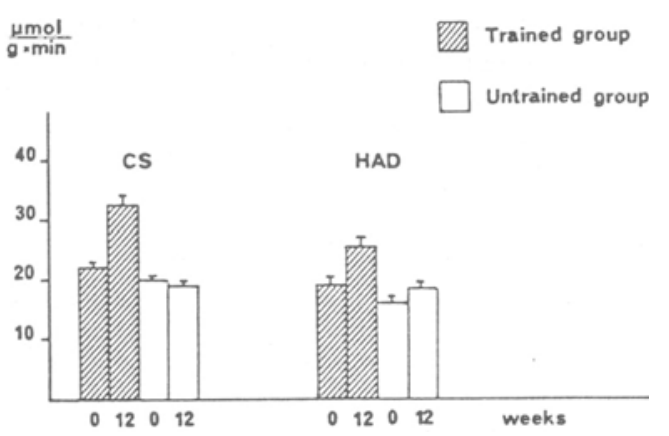

Figure 1. The activities of the enzymes citrate synthase (CS) and 3-OH-acyl-CoA dehydrogenase (HAD) in muscle tissue from pigs of the trained and untrained $\square$ groups, measured at the beginning ( 0 weeks) and at the end of the 12-week experıment. The activitıes are expressed as $\mu \mathrm{mol} / \mathrm{g}$ dry weight $\times$ min.

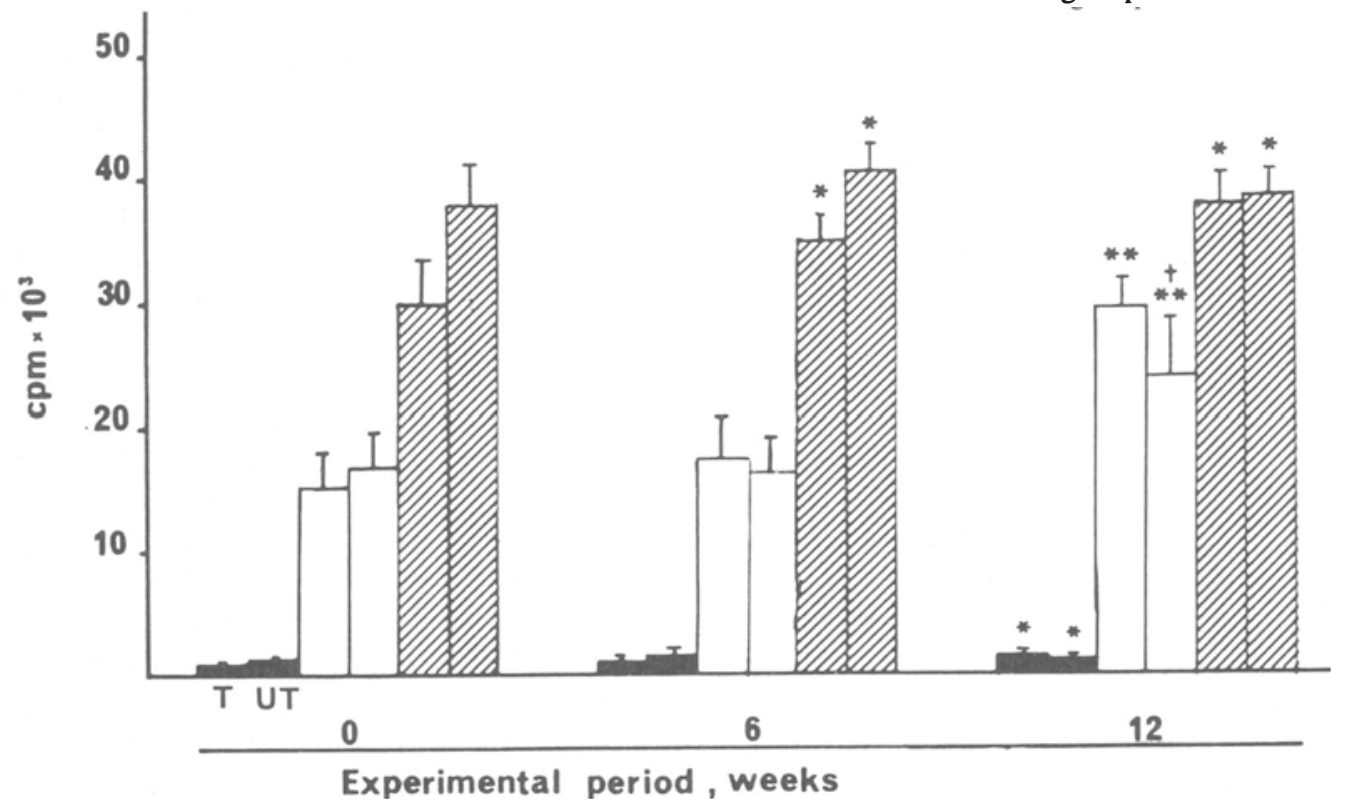

this 12-weeks; the activity of HAD also increased, but not significantly $(0.05<\mathrm{p}<$ 0.08 ). The activities of these enzymes did not change in the untrained group (Fig. 1). On all test occasions PBL from the trained and untrained pigs responded equally well to PWM and PHA stimulation (Fig. 2).

Lymphocytes obtained from the 2 control pigs responded equally well to mitogen stimulation irrespective of whether they were grown in cultures supplemented with fetal calf serum or with serum from either group of experimental animals. The same results were obtained with serum collected both before and after the training period (Table 1).

Also, when the 2 litters were compared (5 littermates in the trained group and 5 litter-

Figure 2. Lymphocyte stimulation tests performed on whole blood obtained from trained $(T)$ and untrained (UT) pigs after 0,6 and 12 weeks of the experimental period. Control cultures $\square$, PHA- $\square$ and

PWM-1nduced 0 blastogenic response (cpm values, mean $\pm \mathrm{SEM}, \mathrm{n}=10$ ).

No difference in the mitogen-induced blastogenic response of the lymphocytes was observed between the groups.

Asterisks $\left({ }^{*}=p<0.05,{ }^{* *}=p<0.01\right)$ indicate significant differences from the blastogenic response obtained on the first test occasion ( 0 weeks). The dagger $(\dagger=p<0.05)$ indicates a significant difference from the blastogenic response obtained on the second test occasion (6 weeks). 
Table 1. Influence of serum factors as reflected by lymphocyte stimulation tests*. The cells were cultured in medium supplemented with serum from trained pigs or untrained pigs or with control serum.

The tests were performed before ( 0 weeks) and after (12 weeks) the experimental period. Values are counts per min (mean \pm SEM).

\begin{tabular}{lllllll}
\hline & \multicolumn{2}{c}{0 weeks } & & \multicolumn{2}{c}{12 weeks } \\
\cline { 2 - 3 } \cline { 5 - 6 } & \multicolumn{1}{c}{ trained } & \multicolumn{1}{c}{ untraned } & & tranned & untraned & \\
\hline PHA & $15696 \pm 1081$ & $13817 \pm 1134$ & & $16654 \pm 259$ & $18710 \pm 1092$ & $21400 \pm 380$ \\
PWM & $26742 \pm 602$ & $26165 \pm 433$ & & $22952 \pm 408$ & $24084 \pm 637$ & $31958 \pm 654$ \\
\hline
\end{tabular}

* Performed with purified mononuclear cells obtained from a control pig.

The mitogens phytohaemagglutinin (PHA) and pokeweed mitogen (PWM) were used.

mates in the untrained group) a similar ability to respond to mitogen stimulation was found on the first 2 test occasions. On the last test occasion the pigs from one of the 2 litters responded significantly $(\mathrm{p}<0.05)$ better to PHA stimulation than the other one.

The blastogenic capacity of porcine PBL was found to increase with age. The response to PWM increased significantly ( $\mathrm{p}<$ 0.05 ) from the first to the second and also from the first to the third test occasion. The magnitude of the response of PBL to stimulation with PHA also increased significantly from the first to the third $(p<0.01)$ and from the second to the third test occasion ( $p$ $<0.05$ ) (Fig. 2).

Furthermore, this pattern was also recorded for the control cultures where a significant $(p<0.05)$ increase in spontaneous mitosis was observed from the first to the last test occasion (Fig. 1).

\section{Discussion}

Exercise can be regarded as a stressor which causes the release of a wide variety of hormonal and neuronal substances (Galbo 1983), which may possibly have a modulatory effect on cells of the immune system (Johnson et al. 1982, Heijnen et al. 1986, and Heijnen et al. 1987). The moderate form of exercise which the animals were subjected to in this study resulted in an increase in the oxidative capacity of skeletal muscle. This was indicated by the increased activities of CS and HAD, a common finding in trained animals (Essén-Gustavsson 1986). Although the training was sufficient to cause skeletal muscle adaption, no alteration of the CMI was observed in the whole blood lymphocyte stimulation tests (Fig. 2). Elevated levels of corticosteroids in plasma has in several studies been shown to influence the CMI. For example, in calves subjected to acute physical exertion the elevation of plasma cortisol correlated well with the observed immuno-suppression (Blecha \& Minocha 1983). Similarly suppression of the CMI and an increase in cortisol levels were demonstrated at the same time in horses after a single strenuous exercise bout (Kurcz et al. 1987). In pigs it has been shown that physiological concentration of cortisol suppress Con A stimulated blastogenesis of the lymphoid cells (Kelley et al. 1982). In addition, the acute stress effect exerted on growing pigs by lorry transportation has been examined by Edfors-Lilja et al. (1987). These authors found the highest response to mitogen stimulation with lymphocytes obtained from the pigs with the lowest levels of serum cortisol. The use of an indwelling ca- 
theter is a necessity when sampling blood for determination of cortisol in stress-susceptible animals, such as the pig. Since it is not possible to have a catheter in situ for as long a period which would have been required in the present study, cortisol determinations were excluded.

Since serum factors are extensively diluted in the whole blood stimulation test, an evaluation of the exercise induced changes in plasma e.g. cortisol, metabolites, ions and non-immunoglobulin which may affect the reactivity of lymphocytes in vivo, was not made possible in this test. Therefore, a stimulation test was performed with purified MNC (from control pigs) grown in cultures supplemented with $20 \%$ of either serumpools from the trained or from the untrained pigs or with control serum. As shown in Table 1, the MNC responded equally well to mitogen stimulation regardless which serum the cells were cultured in. The intensity of exercise and the subsequent level of cortisol in plasma begins, in humans, to rise at a critical level of about $60 \%$ of the subject's maximal aerobic power $\left(\mathrm{V}_{02} \max \right)$ (Davis \& Few 1973). Whether this is in accordance with the situation in the pig is unclear but obviously the physical exercise of the experimental pigs did not release serumfactors that altered the capacity of lymphocytes to respond to mitogen stimulation.

Sometimes, pigs seem to tolerate stress rather well since they survive the crowding and mixing in modern piggeries.

At the last whole blood lymphocyte stimulation test, a difference between the 2 litters in the magnitude of the blastogenic response to PHA was observed. The litter which showed an increased PHA-induced blastogenic response had a mean serum vitamin $E$ value of $3 \mathrm{mg} / \mathrm{l}$. This value was significantly higher ( $p<0.01$ ) than the corresponding value, 2.3 $\mathrm{mg} / \mathrm{l}$, for the more poorly responding litter (unpublished observations). Since all pigs were fed the same diet, the difference in the concentration of vitamin $\mathrm{E}$ in serum must be referred to differences in absorption and retention of vitamin E compounds (GalloTorres 1980).

In previous study (Jensen et al., 1988) it was proposed that $3 \mathrm{mg}$ of vitamin E/1 serum was a threshold value for porcine PBL, below which an impaired blastogenic response can be expected. The observed difference between the litters at the last whole blood lymphocyte stimulation test might therefore be explained by the difference in the concentration of vitamin $\mathrm{E}$ in serum.

An increased capacity of PBL to respond to PHA and PWM induced stimulation was noted in both the trained and untrained group of pigs after the 12-week experimental period. Such a phenomenon has previously been observed both in pigs (Jensen et al. 1988) and in calves (Fossum et al. 1986) and has been interpreted as an effect of ageing.

In conclusion, the present data demonstrate that regular moderate exercise, as a model for chronic physical stress, does not alter the capacity of the PBL to respond to mitogen stimulation in growing pigs.

\section{Acknowledgements}

This work was supported by grants from the Swedish Council for Forestry and Agricultural Research.

The author wishes to thank Docent Caroline Fossum for scientific advice and critical views on the manuscript and Professor Sune Persson and Docent Birgitta Essén-Gustavsson for critical reading of the manuscript.

\section{References}

Andersson $K$. SLU-feeding scale for growing fattening pigs. The Research Conference. Report from the Research Information Centre at the Swedish University of Agricultural Sciences. 1985, 67:2. 
Blecha F, Minocha HC: Suppressed lymphocyte blastogenic responses and enhanced in vitro growth of infectious bovine rhinotracheitis virus in stressed feeder calves. Amer. J. vet. Res. 1983, 44, 2145-2148.

Davis CTM, Few JD Effects of exercise on adrenocortical function. J. appl. Physiology. 1973, 35, 887-891.

Edfors-Lilja I, Lundström K, Nyberg L, Rundgren $M \cdot$ Influence of the hal locus and standardized stress on antibody response and in vitro reactivity of peripheral blood lymphocytes in pigs. Vet. Immunol. Immunpathol. 1987, 14, 157-171.

Eskola J, Runskanen O, Soppı E, Viljanen MK, Järvinen $M$, Tolvonen $H$, Kuovalainen $K$ Effect of sport stress on lymphocyte transformation and antibody formation. Clin. exp. Immunol. 1978, 32, 339-345.

Essén B, Lindholm A, Thornton J Histochemical properties of muscle fibre types and enzyme activities in skeletal muscles of standardbred trotters of different ages. Equine Vet. J. 1980, 12, 175-180.

Essén-Gustavsson B, Karlström K, Lindholm A: Fibre types, enzyme activities and substrate utilisation in skeletal muscles of horses competıng in endurance rides. Equine Vet. J. 1984, 16, 197-202.

Essén-Gustavsson B: Activity and inactivity - related muscle adaption in the animal kingdom. In Biochemistry of exercise VI. Ed. Bengt saltin. Human Kınetics. Publishers Champaign Illinois. 1986, 436-444.

Fossum C, Larsson B, Matsson $P$ Development of mononuclear cell subpopulations and their function during calf hood. J. Vet. Med. 1986 B, 33, 518-527.

Galbo $H$ Hormonal and metabolic adaption to exercise. Georg Thieme Verlag, Stuttgart, New York 1983.

Gallo-Torres HE: Absorption. In: L. J. Machlin (Ed.): Vitamin E - A Comprehensive Treatise. Vol. 1. Marcel Dekker Inc., New York 1980.

Heynen CJ, Bevers C, Kavelaars A, Balleux RE. Effect of alpha-endorphin on the antigen - induced primary antibody response of human blood B cells in vitro. J. Immunol. 1986, 136, 213-216.
Heljnen CJ, Croiset G, Zilstra J, Balleux RE Modulation of lymphocyte function by endorphins. Ann. N.Y. Acad. Sci. 1987, 496, 161-165.

Jensen M, Fossum C, Ederoth M, Hakkarainen J The effect of vitamin $\mathrm{E}$ on the cell-mediated immunity in pigs. J. Vet. Med. B. 1988, 35, 549-555.

Johnson HM, Smith EM, Torres BA, Blalock JE: Regulation of the in vitro antibody response by neuroendocrine hormones. Proc. Natl. Acad. Sc1. (USA) 1982, 72, 4171-4174.

Kelley $K W$ Stress and immune function: A bibliographic review. Ann. Rech. Vét. 1980, 11, 445-478.

Kelley KW, Mertsching HJ, Mathison BA, Kissinger $C R \cdot$ Physiologic concentrations of cortisol suppress mitogenesis of porcine lymphoid cells. J. Anim. Sc1. 1982, 55, 1, 191.

Kurcz EV, Lawrence LM, Kelley KW, Miller PA The effect of intense exercise on the cell-mediated immune response of horses. Subm. for publication 1987.

Monjan AA Stress and immunologic competence: Studies in animals. In "Psychoneuroimmunology" Ed. R. Ader. Academic Press, New York 1981, 185-228.

Relland $S$. Osteochondrosis in the pig. A morphologic and experimental investigation with special reference to the leg weakness syndrome. Thesis 1975.

Rülcker $C$. The influence of physical training and short-time physical stress on colour, fluid loss, $\mathrm{pH}$, adenosine triphosphate and glycogen of the gracilis muscle in pigs. Acta vet. scand. Suppl. 24, 1968.

\section{Sammanfattning}

Effekten av regelbunden träning på det cell-medierade immunforsvaret hos gris

Sambandet mellan regelbunden träning och immunokompetens studerades hos växande grisar.

Tio grisar tränades 5 ggr i vecken på en rullande matta medan 10 kullsyskon lämnades inaktiva $i$ sina boxar.

Träningseffekten i skelettmuskulaturen utvärderades med bestämningar av de oxidativa enzymerna CS och HAD. 
Det cellmedierade immunförsvaret undersöktes med lymfocytstımuleringstester utförda på helblod samt framrenade mononucleära celler.
Slutligen konstaterades att den växande grisens cellmedierade ımmunförsvar inte påverkas av regelbunden fysisk aktivitet.

\section{(Accepted June 1, 1988)}

Reprints may be requested from: Marianne Jensen, Dept. of Medicıne and Surgery, Faculty of Veterınary Medicine, Swedısh University of Agricultural Sciences,

P. O. Box 7018, S-75007 Uppsala, Sweden. 